\title{
SCHMEISER V. MONSANTO: A CASE COMMENT
}

\author{
EDWARD (TED) YOO AND ROBERT BOTHWELl*
}

\section{INTRODUCTION}

The Supreme Court of Canada first wrestled with the patentability of higher life forms in the Harvard mouse case.' Their decision to refuse patents claiming genetically modified animals, and by extension plants, was a major disappointment to many in the biotechnology industry in Canada. Canada stood alone amongst its G8 partners as the one jurisdiction where such patents could not be obtained. Dire predictions about the future of biotechnology research and development in Canada were made.

When the Supreme Court granted leave to appeal ${ }^{2}$ to Mr. Schmeiser in his legal battle with industry giant Monsanto, it was thought by many that the rights of patentees could take another blow, and further set back Canada's growing biotech industry. Others more optimistically believed that the Supreme Court had an opportunity to expand patent rights in the biotech field.

\section{FACTS}

The respondents, Monsanto Company and Monsanto Canada Inc., are the owner and licensee respectively of a patent titled "Glyphosate-Resistant Plants." The patent was granted in 1993 and is directed to a chimeric ${ }^{3}$ gene that confers upon canola plants resistance to glyphosate-based herbicides. The resulting plant is named "Roundup Ready Canola" by Monsanto, referring to the resistance demonstrated by the modified canola plant towards Monsanto's own glyphosate-based herbicide "Roundup."

Monsanto licenses its Roundup Ready Canola to farmers for a fee, provided they sign a Technology Use Agreement (TUA), which entitles the farmer to purchase Roundup Ready Canola from an authorized Monsanto agent. The TUA restricts the farmer from using the seed to plant more than one crop and requires the crop to be sold only for consumption to a commercial purchaser authorized by Monsanto. The farmer is also prohibited from selling or giving the seed to a third party. Additionally, the terms of the TUA provide Monsanto with the right to inspect the fields of contracting farmers in order to verify compliance.

Ted Yoo is a registered patent agent and partner with Bennett Jones LLP in their Edmonton office. Robert Bothwell is a student-at-law with Bennett Jones LLP. The helpful comments of Simon Foxeroft are gratefully acknowledged.

1 Harvard College v. Canada (Commissioner of Patents), [2002] 4 S.C.R. 45 [Harvard College]. Harvard College applied for a patent for a genetically modified mouse comprising a human oncogene, a so-called oncomouse. The Supreme Count had an earlier opportunity to deal with the issue in Pioneer HI-Bred Lid. v. Canada (Commissioner of Patents), [1989] I S.C.R. 1623, but decided the appeal on another ground.

2 Monsanto Canada v. Schmeiser, [2002] S.C.C.A. No. 437.

3 A chimeric gene is a gene that does not exist in nature and that is constructed from genes from different species. 
Percy Schmeiser has farmed canola in Saskatchewan for over 50 years, more recently behind the corporate veil of Schmeiser Enterprises Ltd. Neither of the appellants (that is, Mr. Schmeiser nor the corporation) had ever purchased Roundup Ready Canola nor had they signed a TUA with Monsanto concerning Roundup Ready Canola. There were, however, a number of farms in the surrounding area of the Schmeiser farm that grew Roundup Ready Canola.

In 1997, Mr. Schmeiser had sprayed Roundup around power poles and ditches surrounding several of his fields. Days later, Mr. Schmeiser noticed that a significant amount of canola that had been sprayed had survived. Mr. Schmeiser conducted further tests and found that approximately 60 percent of the plants that had been sprayed continued to grow several days later. Mr. Schmeiser used seed from this resistant crop to plant all his fields the following crop year, which has been described as a common practice among canola farmers.

In 1997 and 1998, several tests were conducted on a number of resulting canola plants and seeds found in and around Schmeiser fields. The test results confirmed the presence of Monsanto's patented gene in a significant portion of Schmeiser canola. As a result, the respondent Monsanto alleged the defendant appellants had infringed its patent relating to genetically modified canola and sought an injunction, damages and an order for delivery up.

\section{Federal Court of Canada}

At trial, the defendants did not deny the fact that Roundup Ready Canola was present in the Schmeiser fields in 1998. They were, however, quite adamant that the patented canola had not been deliberately planted and advanced several arguments in defense of the allegations of infringement.

The defendants advanced the argument that the patent was invalid on the ground that the subject matter was not patentable, relying on the Harvard College decision. Justice MacKay rejected this argument and distinguished this case from Harvard College in that Harvard College concemed the patentability of a mammal whereas the claims in this case were limited to the chimeric gene and cells including the gene. ${ }^{4}$

Justice MacKay also rejected the argument advanced by the defendants that the plaintiffs had subsequently waived their patent rights by releasing the invention into the environment without maintaining control over its dispersion. Justice MacKay pointed out that the plaintiffs conduct (such as the licensing agreements, monitoring authorized growers, etc.) is inconsistent with the notion that Monsanto had lost or waived its exclusive rights. ${ }^{5}$

Justice MacKay came to the conclusion that, on a balance of probabilities, Monsanto's patent had been infringed by Schmeiser Enterprises Ltd. In 1997, the defendants discovered that Roundup tolerant canola was present in their field. By using the seeds from this canola (which the defendants knew or ought to have known was Roundup tolerant) to plant crops the following year, the defendants infringed upon the plaintiffs exclusive rights. Further 
infringement occurred upon the harvesting and selling of this crop in 1998. Justice MacKay pointed out that the infringement occurred regardless of whether or not it was intended and regardless of whether or not the defendants actually sprayed Roundup on the plants during the growing period. Monsanto was awarded an injunction preventing further use of the Roundup tolerant canola, an order for delivery up of any plants or seeds from the 1997 and 1998 crops, and damages. The corporation alone, and not Mr. Schmeiser, was held liable for the infringement. The defendants appealed.

\section{Federal Court of APPeal.}

There were four main issues addressed by the Federal Court of Appeal. The first concerned whether the patent was actually infringed, given the fact that Mr. Schmeiser did not actually use Roundup on his crop in 1998. To determine if infringement actually occurred, Sharlow J.A. adopted a "purposive construction" approach to interpreting the claims of the patent. ${ }^{6}$ As a result, she agreed with the conclusion reached by the trial court that "the essence of each claim was the Monsanto Gene" and concluded that the use of Roundup is not a necessary element to finding infringement. It was found that the act of infringement occurred by planting the seeds and harvesting the plants.

The second issue under appeal was whether the trial judge correctly dismissed the significance of how the Roundup resistant canola was introduced into the environment surrounding the Schmeiser farm. Justice Sharlow addressed this issue by first examining the conflicting rights of the parties (the patent holder and the owner of the plant) and concluded there was no reason to support the proposition that the rights of the patent holder should be superseded by the rights of the plant owner. ${ }^{8}$ In response to the argument that the "innocent infringer" should not be held liable, Sharlow J.A. stated that Mr. Schmeiser knew or ought to have known that the seed he used to plant the 1998 crop was Roundup resistant, and under those circumstances, the alleged infringer could still be held liable. Justice Sharlow also agreed with the conclusion reached by the trial judge that Monsanto had not waived their exclusive patent rights by simply allowing the Roundup resistant canola to be released into the environment. ${ }^{10}$ Given the above considerations, it was concluded that the source of the Roundup resistant canola was irrelevant.

The third issue raised on appeal dealt with whether much of the evidence submitted at trial was admissible. The Appellate Judge considered the arguments put forth by the appellants and concluded that there was no error made by the Trial Judge with respect to the admissibility of evidence and thus no reason for the Appellate Court to intervene." Similarly, on the fourth and final issue, Sharlow J.A. found no error in the relief granted by the Trial Judge. 


\section{SUPREME COURT}

The Supreme Court decision in Harvard College arguably left a large gap in the protection available to biotech inventors working with transgenic plants and animals. Following the majority decision in the present case, ${ }^{12}$ it is likely that the gap has now been closed.

In Harvard College, it was made clear that processes and the modified or isolated genes and cells, which are the biotech building blocks, were patentable, but that living higher life forms were not patentable. It is worthwhile examining the claims of the oncomouse patent that were allowed by the Patent $O$ ffice and not subject to the appellate process. Those claims are variously directed at a method of testing a suspected carcinogen by exposing an oncomouse to the substance and detecting tumours; a method of producing a transgenic mammal; a somatic cell culture comprising the oncogene; and plasmids, ${ }^{13}$ which comprise the oncogene.

Therefore, the Harvard mouse patent, as issued by the Patent Office, would block the way of a person who sought to reproduce the process of creating an oncomouse or who used an oncomouse to test for carcinogenicity of test compounds, but would not block a person who obtained a breeding pair of oncomice and bred their offspring, either for their own use or for resale.

This limitation on biotech patents was a significant obstacle to companies like Monsanto, who developed transgenic plants but could not count on patent protection for the actual plants themselves. Now with the Supreme Court decision in Schmeiser, biotech companies are assured that their patents may cover the act of growing and harvesting the transgenic plants, despite the fact that the plants themselves may not be patented.

The Monsanto patent claims are directed to the following inventions:

the chimeric gene;

a cloning vector or plant transformation vector including the chimeric gene;

a plant cell including the chimeric gene; and

methods for producing a herbicide resistant plant using the chimeric gene.

The central issue in this case was the question of "use" of the invention under the infringement provisions of the Patent Act. ${ }^{14}$ The majority decided that the saving and planting of seed, then harvesting and selling plants, containing the patented chimeric gene, was in fact use of the patented invention. 's It is likely that this case will be cited often in the future for the seven propositions relating to "use" clearly laid out by the majority. ${ }^{16}$ These seven propositions are essentially as follows. The ordinary dictionary meaning of the word denotes use with a view to production or advantage. Therefore, a "use" will infringe a patent if the patentee has been deprived in whole or in part of the full enjoyment of the monopoly

Monsanto Canada v. Schmeiser. 2004 SCC 34 [Schmeiser].

A plasmid is one example of a cloning vector used to inser a foreign gene into a target cell.

Patent Act, R.S.C. 1985, c. P-4.

Schmeiser, supra note 12 at para. 69.

Ibid. at para. 58. 
conferred by the patent. An examination of the commercial benefit to be derived from the invention is useful to determine whether full enjoyment of the monopoly has been impaired.

It is important to consider the practical effect of the fact the gene in question was a chimeric gene. As such a gene did not exist in nature, it could be claimed without the additional limitation of being in isolated or purified form. If a gene is known to exist in nature, it must be claimed in isolated form. Otherwise, it would not be novel and any living thing having the gene in its genome would infringe such a patent. A claim for a gene in its isolated form can only be infringed by someone working in a laboratory.

However, it is entirely possible, and it is common practice, to claim a cell that has been transformed by the gene of interest. ${ }^{17}$ The claimed cell need not be claimed in isolated form, as it does not exist in nature. A mouse cell with a human oncogene did not previously exist in nature and therefore could be the subject of a patent claim.

A claim to a transformed cell, which did not previously exist in nature, will be infringed by natural reproduction of the plant or animal that is made up of such transformed cells. Any person who directs such reproduction would infringe such a patent claim. As stated by McLachlin C.J.C. and Fish J.:

the law holds that a defendant infringes a patent when the defendant manufactures, seeks to use, or uses a patented part that is contained within something that is not patented, provided the patented part is significant or important. In the case at bar, the patented genes and cells are not merely a "part" of the plant; rather, the patented genes are present throughout the genetically modified plant and the patented cells compose its entire physical structure. $^{18}$

As recognized by the majority in Schmeiser, this is not a particularly novel point of law; rather it is a well accepted principle that has found many applications in the case law. ${ }^{19}$ However, all previous precedents involved patents involving machines, which are obviously inanimate.

The minority found that the precedential value of mechanical cases when considering patents involving higher life forms to be quite low. The minority believed that the majority decision to be irreconcilable with the majority decision in Harvard College. ${ }^{20}$ Simply stated, if the plant itself cannot be patented, then a patent directed to genes and cells should not be construed to include within its scope, acts limited to the growth and harvesting of the plant itself. Justice Arbour construed the claims and concluded, relying on two important principles in patent law, that the gene patent claims and plant cell claims should not be construed to grant exclusive rights over the plant and its progeny. ${ }^{21}$ First, claims must be predictably construed. Predictability is the result of tying the patentee to its claims. Second, what is not claimed is disclaimed. Therefore, because Monsanto did not (could not) claim the

Provided the cell and gene are heterologous, i.e. they are from different species, or the combination is otherwise unnatural.

Schmeiser, supra note 12 at para. 42.

lbid. at paras. 43-49.

lbid. at paras. 108-109.

Jbid. at para. 129. 
canola plant itself, it claimed only the gene and cells. Therefore the plant itself is disclaimed. This logic has a superficial appeal and does reconcile with the Harvard College decision.

However, it was rebutted by the majority:

It is uncontested that Monsanto's patented claim is only for the gene and cell that it developed. This, however, is the beginning and not the end of the inquiry. The more difficult question - and the nub of this case - is whether, by cultivating plants containing the cell and gene, the appellants used the patented components of those plants. The position taken by Arbour $J$, assumes that this inquiry is redundant and that the only way a patent may be infringed is to use the patented invention in isolation.

This position flies in the face of century-old patent law, which holds that where a defendant's commercial or business activity involves a thing of which a patented part is a significant or important component, infringement is established. It is no defence to say that the thing actually used was not patented, but only one of its components. 22

Accordingly, the majority determined that there was no reason to distinguish between mechanical inventions and biotech inventions involving living matter when considering the issue of use:

Under the present [Patent] Act, an invention in the domain of agriculture is as deserving of protection as an invention in the domain of mechanical science. Where Parliament has not seen fit to distinguish between inventions concerning plants and other inventions, neither should the courts. ${ }^{23}$

Thus, the lack of express intent from our legislators is used in this case to argue in favour of expansive patent rights over biotechnology. Interestingly, this same rationale was used in Harvard College to deny patent coverage for higher life forms.

While the majority emphasized commercial value and exploitation of the invention to determine whether or not an invention is being used and not the issue of claim construction, the majority decision comes dangerously close to considering commercial value as a factor in construing the claims - which would be a mistake. It is well established that claim construction is the first and primary step in the process of determining whether or not infringement has taken place. These principles of claim construction were laid out in the Supreme Court's decision in Whirlpool Corp. v. Camco Inc. ${ }^{24}$ It is apparent that the majority and the minority have construed the claims differently, and arguably that is the source of their disagreement.

The majority construed the claims literally and have followed the well-established guidelines that have been accepted and widely applied. It does not matter that the result is seemingly incongruous with the denial of patent protection in Harvard College. Conversely, Arbour J. sought to resolve the incongruity and so limited the scope of the claims: 
The plant cell claim ends at the point where the isolated plant cell containing the chimeric gene is placed into the growth medium for regeneration. Once the cell begins to multiply and differentiate into plant tissues, resulting in the growth of a plant, a claim should be made for the whole plant. However, the whole plant cannot be patented. 25

In effect, the minority seeks to add the word "isolated" to the claims to the plant cell and gene. Justice Arbour cites no authority for this proposition, as it seems none is available. To the dissenting justices, the rationale for limiting the scope of the claims is to prevent patentees from doing indirectly what they could not do directly. In other words, if a patentee cannot directly claim a higher life form, then a patent directed to genes and cells should not be enforced against higher life forms, which then would provide indirect patent coverage where none should exist. However, this reasoning is based on a principle of equity which has not yet found its way into patent law. In light of the principles stated in the Whirlpool case, it is incorrect to read such a limitation into the patent claims and it is respectfully submitted that the majority correctly construed the claims.

\section{Conclusion}

The definition of invention found in the Patent Act stems from wording first developed in the 18 th century. ${ }^{26}$ It has been malleable enough to encompass innovations unthinkable even 50 years ago. However, it had been determined not to be elastic enough to include animals and plants. The Supreme Court has invited Parliament to act if it chooses to do so.

Despite that prior interpretation of the Patent Act, a majority of the Supreme Court has now found that straightforward application of long accepted principles of patent law extended patent protection to plants, even though the patent claims were limited to genes and cells. Practitioners of biotech patent law will be quick to ensure that their patent applications for transgenic plants and animals are crafted to take advantage of this ruling. It remains to be seen whether or not Parliament will find it necessary to intervene. 